\title{
PERAN KUD DALAM PEMBERDAYAAN EKONOMI PENAMBANG MINYAK TRADISIONAL DI DESA
}

\author{
Khofifatu Rohmah Adi ${ }^{1}$, Fatiya Rosyida ${ }^{2}$ \\ Diterima 26 Juli 2018, Dipublikasikan 31 Oktober 2018 \\ CPenulis (2018)
}

\begin{abstract}
The welfare of the people is the nation's aspiration which is also clearly and explicitly stated in the opening of the 1945 constitution. In fact to achieve prosperity, there needs to be Koperasi between the government and the community. The government as the ruler plays a role in making policies that aim to prosper the people. Ironically the gap is seen as shown by the Gini ratio in March 2014 which increased from the previous year. The concept of people's economy is the solution to Bung Hatta's thought, namely where all economies can be applied with the principles of, by, and for the people. In harmony with this thought a cooperative was born. This study will discuss the role of cooperatives for traditional oil miners in Wonocolo village. The research method used is descriptive qualitative. Koperasi as an entity that is given trust by the government as a container in the management of old wells so that the SDA can provide maximum benefits and revenues for the State for the greatest prosperity of the people. Economic empowerment carried out by food source cooperatives through capital facilities and as a place for communities around the location of old wells to be able to utilize old wells as a source of income.
\end{abstract}

\section{Keywords}

Welfare, Oil Miner, KUD

\section{PENDAHULUAN}

Kesejahteraan masyarakat merupakan cita-cita bangsa yang juga termaktub secara jelas dan tersurat dalam pembukaan undang-undang dasar 1945. Sejatinya untuk mencapai kesejahteraan tersebut perlu adanya kerja sama antara pemerintah dan masyarakat. Pemerintah selaku penguasa berperan dalam membuat kebijakan-kebijakan yang bertujuan untuk menyejahterakan rakyatnya. Kebijakan-kebijakan inilah yang pada nantinya dapat digunakan untuk menaungi masyarakat untuk dapat berdaya sehingga peningkatan kehidupan ekonomi masyarakat dapat terlaksana.

Kesejahteraan masyarakat bukan saja hanya dilihat dari seberapa baik tingkat ekonomi atau pendapatan masyarakat. Lebih dari itu, kesejahteraan meliputi bagaimana tingkat ekonomi masyarakat, bagaimana pendidikan masyarakat serta bagaimana tingkat kesehatan masyarakat. Bagaimana tingkat ekonomi masyarakat pada nantinya akan menunjukkan seberapa besar daya beli atau standar hidup masyarakat. Bagaimana pendidikan diperoleh oleh suatu masyarakat dapat menunjukkan seberapa tingkat pengetahuan masyarakat. Kualitas kesehatan yang tinggi sangat diperlukan, hal ini karena kesehatan merupakan modal dasar bagi setiap individu untuk dapat bekerja dengan baik, sehingga masyarakat memiliki tingkat produktivitas yang tinggi.

1 Prodi Pendidikan IPS, Fakultas Ilmu Sosial Universitas Negeri Malang

khofifatu.rohmah.fis@um.ac.id

2 Jurusan Geografi, Fakultas Ilmu Sosial Universitas Negeri Malang

Jurnal Teori dan Praksis Pembelajaran IPS Volume 3, No.2, 2018, ISSN 2503-5307 
Sebagaimana kita lihat masalah kesenjangan masih menjadi PR bagi pemerintah kita. kesenjangan ini meliputi kesenjangan ekonomi dan kesenjangan non ekonomi. Kesenjangan ekonomi dapat kita lihat dari tingkat kemiskinan, yang bahkan sekarang berada dalam tahap kronis. Data statistik dari BPS tentang koefisien gini provinsi 2002-2017 menunjukkan setiap tahun dan setiap semester gini ratio tiap-tiap provinsi memiliki angka rata-rata naik. Gini ratio tersebut menunjukkan bahwa masih ada ketimpangan yang terjadi di Indonesia. Selain itu persentase kemiskinan di provinsi Jawa Timur tahun 2014 sebesar 12,42\% sedangkan tahun 2015 sebesar 12,34\% (www.bps.go.id). Berbagai hal yang menjadi penyebab lambatnya penurunan kemiskinan antara lain adalah karena pertumbuhan ekonomi yang tidak memenuhi target yakni sebesar 6,3\% sedangkan pertumbuhan yang dicapai 5,78\%. Pada bulan Juli dan Agustus 2013 terjadi inflasi yang cukup tinggi yang diakibatkan oleh kenaikan harga BBM (Iryanti:2014). Ketimpangan yang terjadi menunjukkan bahwa kaum yang kaya semakin kaya dan yang miskin semakin tertinggal jauh di belakang. Padahal sejatinya negara kita ini adalah negara yang menganut demokrasi ekonomi di mana kepemilikan individu diakui, masyarakat yang tidak mampu memiliki peluang untuk mengkreasi kekayaan dalam bentuk kepemilikan dan mendapatkan sistem pembagian yang adil dalam pendapatan (Hatta. 2015).

Kesenjangan ekonomi jika tidak segera diatasi akan berdampak pada kohesi sosial dan politik, serta akan berdampak pada melemahnya pertumbuhan ekonomi. Pengaruh terhadap kohesi sosial akan menimbulkan lingkungan yang tidak aman serta masyarakat tidak mampu untuk memenuhi kebutuhannya. Akibat yang terjadi adalah kejahatan kian marak. Kesulitan ekonomi akibat dari kesulitan dalam mencari nafkah mengakibatkan orang lupa diri, akibatnya banyak yang mencari jalan pintas dengan melakukan kejahatan seperti penipuan, pembegalan, pencurian dan lain sebagainya. Untuk mencegah hal tersebut maka diperlukanlah suatu perkumpulan yang dapat mewadahi masyarakat dalam rangka melakukan kegiatan ekonomi yang sesuai dengan sistem demokrasi ekonomi sehingga tiap orang dapat memperoleh pekerjaan dan penghidupan yang layak.

Koperasi merupakan suatu badan usaha yang sesuai dengan demokrasi ekonomi. Hal ini dikarenakan prinsip dasar dari koperasi yakni untuk menyejahterakan anggotanya bukan hanya sekedar kesejahteraan perseorangan. Koperasi juga dinilai mampu memberikan manfaat yang besar secara luas bagi perekonomian dan sekaligus bagi para anggotanya.

Secara sempit manfaat koperasi bagi anggotanya adalah untuk menyejahterakan anggotanya, sehingga koperasi tergerak dilandasi atas kepentingan bersama. Untuk mencapai tujuan ini semua anggota bekerja secara bersama-sama dengan gotong royong, dengan cara kerja yang demikian itu pada nantinya setiap anggota memperoleh imbalan sesuai dengan jasa yang disumbangsihkan. Kartasapoetra (2001) menjelaskan bahwa setiap peran anggota koperasi akan memperoleh imbalan yang adil berupa pembagian keuntungan yang diperoleh dari koperasi.

Latar belakang berdirinya koperasi di Indonesia tidak lepas dari peran Raden Aria Wiriatmadja. Serta berkembang jauh lebih pesat pada era Budi Utomo. Pergerakan Budi Utomo memiliki pemikiran bahwa rakyat yang lemah ekonominya tidak akan bisa membentuk negara yang kuat. Berdasarkan pemikiran tersebut muncullah gagasan untuk menolong diri sendiri dengan mendirikan suatu perkumpulan, suatu badan usaha Koperasi. Dengan adanya koperasi diharapkan rakyat yang lemah dan tertindas akan dapat bangun, dan berdiri sendiri apabila memakai perusahaan yang lazim dipakai oleh bangsa asing. Hal yang sama juga terjadi di 
Negara maju, di barat koperasi lahir sebagai upaya perlawanan terhadap ketidakadilan pasar (Soetrisno: 2003)

Koperasi merupakan suatu badan usaha yang beranggotakan orang-orang yang berbadan hukum yang berasaskan gotong royong. Ciri utama dari koperasi adalah di mana tujuannya bukan semata-mata mengejar keuntungan, akan tetapi koperasi memiliki tujuan untuk menyejahterakan anggotanya. Ciri ini tertuang dalam prinsip koperasi yang dijabarkan pada UU No 25/1992 tentang Perkoperasian yaitu (1) keanggotaan bersifat sukarela dan terbuka, (2) pengelolaan dilakukan secara demokratis, (3) pembagian sisa hasil usaha dilakukan secara adil sebanding dengan besarnya jasa usaha masing-masing anggota, (4) pemberian balas jasa yang terbatas terhadap modal, dan (5) kemandirian.

Koperasi menjadi suatu organisasi yang cukup mampu diandalkan keberadaannya. Hal ini sesuai dengan pendapat dari Heriyono (2012) yang menyatakan bahwa organisasi koperasi merupakan organisasi yang kuat yang mampu bertahan di tengah situasi sulit. Hal ini dikarenakan koperasi merupakan organisasi milik bersama yang memiliki cita-cita dari anggota dan oleh anggota, sehingga rasa memiliki organisasi sangat tinggi. Karena memiliki cita-cita dari dan untuk anggota, organisasi ini mampu memperoleh loyalitas yang tinggi dari anggota. Loyalitas yang tinggi dari anggota inilah yang dapat membuat koperasi tetap kokoh di tengah situasi ekonomi yang bergejolak. Cerita sukses koperasi banyak berperan dalam perbaikan ekonomi rakyat. Ekonomi rakyat identik dengan usaha mikro, yang mana usaha ini banyak digeluti oleh sebagian besar rakyat Indonesia. Koperasi masuk dalam setiap kegiatan ekonomi rakyat.

Di tengah situasi ekonomi yang tidak menentu, sayangnya tidak semua koperasi bisa melalui jalan mulus. Banyak dari koperasi-koperasi yang ada tidak mampu bertahan, dan tidak mampu mewujudkan peran koperasi. Peran yang menjadi cita-cita koperasi yakni menyejahterakan masyarakat umumnya serta anggota khususnya. Banyak sekali kendala di lapangan mulai dari kurangnya pengetahuan akan manfaat dan keberadaan koperasi hingga kurangnya permodalan koperasi.

Peran koperasi dalam pembangunan ekonomi Indonesia yang berbasis kerakyatan adalah sangat penting. Koperasi Unit Desa (KUD) merupakan koperasi serba usaha yang beranggotakan penduduk desa dan berada di pedesaan. Melalui KUD masyarakat dapat melakukan segala aktivitas ekonomi seperti simpan pinjam, pemasaran, layanan jasa, kegiatan konsumsi maupun produksi hasil usaha.

Desa Wonocolo merupakan suatu desa yang berada di kecamatan Kedewan kabupaten Bojonegoro, terletak di perbatasan Jawa Timur dan Jawa Tengah. Mayoritas masyarakat Desa menggantungkan hidupnya dari sumur minyak tua. Uniknya masyarakat disana beraktifitas secara tradisional untuk memproduksi minyak dari sumur-sumur tua sejak lebih dari 100 tahun. Adanya KUD Sumber Pangan di desa Wonocolo diharapkan dapat menyokong kegiatan ekonomi warga sehingga kesejahteraan masyarakat dapat tercapai.

\section{METODE}

Penelitian ini dirancang dengan menggunakan pendekatan kualitatif yaitu sebuah penelitian untuk mengungkapkan gejala secara holistik kontekstual melalui pengumpulan data dengan menggunakan peneliti sebagai instrumen kunci. Informan adalah pengelola koperasi. Informasi diperoleh melalui wawancara mendalam di desa Wonocolo, Bojonegoro. Peran koperasi sebagai variabel penelitian dilihat dari partisipasi koperasi dalam mendukung kegiatan ekonomi 
masyarakat. Selain itu variabel ke dua yakni potensi dan permasalahan merupakan keunggulan dan kelemahan KUD dalam upaya pemberdayaan ekonomi masyarakat. Data dianalisis menggunakan teknik analisis interaktif yang terdiri dari 4 tahap, yaitu (1) pengumpulan data, (2) penyajian data, (3) reduksi data, dan (4) penarikan kesimpulan/verifikasi (Miles \& Huberman, 2007).

\section{HASIL DAN PEMBAHASAN}

Wonocolo merupakan nama sebuah desa di kecamatan Kedewan Kabupaten Bojonegoro. Secara geografis desa ini berada di perbatasan antara propinsi Jawa Timur dan Jawa Tengah. Desa ini berada di areal perbukitan kapur, dan dikelilingi oleh pohon-pohon jati yang sudah tak lagi rimbun, sehingga hawa panas begitu terasa ketika berada di daerah tersebut. Desa Wonocolo berbatasan langsung desa Banyu Urip di sebelah timur, sebelah barat ada desa Kedewan, sebelah selatan berbatasan dengan desa Ngantru, dan sebelah Utara berbatasan dengan desa Kali gede.

Ratusan tahun yang lalu desa Wonocolo pernah menjadi sumber ekonomi bagi Belanda, di mana di wilayah tersebut banyak terdapat sumur bekas penambangan minyak Belanda. Kegiatan penambangan yang dilakukan oleh Belanda tersebut berlangsung sampai kedatangan Jepang ke Indonesia. Setelah ditinggalkan oleh Belanda sumur-sumur bekas penambangan Belanda tersebut digunakan oleh warga untuk memenuhi kebutuhan ekonomi. Dengan berbekal keahlian yang mereka miliki secara turun temurun mereka mengambil minyak secara tradisional. Pengambilan tersebut dilakukan secara kelompok, biasanya satu sumur dikelola oleh sekitar 10-20 orang. Penambangan secara kelompok ini berkaitan dengan modal yang diperlukan dalam penambangan.

Peralatan yang digunakan untuk menambang menggunakan mesin bekas mobil tak terpakai yang direnovasi. Dalam pelaksanaannya masyarakat setempat acapkali tidak dibekali dengan alat perlindungan diri sebagai standar dari keamanan dan keselamatan kerja. Hal ini tentu saja memiliki risiko yang sangat besar bagi keselamatan para penambang.

Secara hukum sumur-sumur bekas peninggalan belanda merupakan aset milik Negara. Sebagaimana tercantum dalam undang-undang No. 86 tahun 1958 tentang nasionalisasi perusahaan Belanda di Indonesia. secara hukum negara berhak memanfaatkan potensi tersebut melalui PT. Pertamina. Namun negara melalui PT Pertamina tidak mengambil manfaat tersebut dikarenakan biaya untuk mengeksplorasi minyak membutuhkan modal yang besar dan tidak sebanding dengan hasil yang diperoleh.

Menjadi suatu ironi jika kekayaan alam tidak dimanfaatkan, sedangkan masyarakat sekitar dalam keadaan ekonomi yang kurang. Undang-undang dasar 1945 pasal 33 ayat 3 yang menyatakan bahwa Bumi, air dan kekayaan alam yang terkandung di dalamnya dikuasai oleh negara dan dipergunakan untuk sebesar-besarnya kemakmuran rakyat. Moh Hatta (2015) menjelaskan bahwa makna yang terkandung dalam pasal 33 UUD 1945 tersebut, bukan berarti negara sendiri yang menjadi pengusaha atau usahawan. Akan tetapi lebih tepat dapat dikatakan bahwa kekuasaan negara terdapat pada pembuat peraturan guna melancarkan jalan ekonomi, serta pembuat peraturan yang melarang pula 'pengisapan' orang yang lemah oleh orang lain yang lebih bermodal atau berkuasa. Dalam pasal lain dalam undang-undang dasar 1945, yaitu pasal 27 UUD 1945 ayat 2 menegaskan bahwa tiap-tiap warga negara berhak atas pekerjaan dan penghidupan yang layak bagi kemanusiaan.

Amanat dalam undang-undang tersebut pada akhirnya mendorong pemerintah untuk mengambil kebijakan. Pemerintah melalui menteri ESDM mengeluarkan peraturan menteri ESDM nomor 1 tahun 2008 tentang pengaturan sumur tua. Dalam bab 1 pasal 2 ayat 1, 2, dan 3 bahwa 
1. Kontraktor memiliki kewajiban untuk mengusahakan dan memproduksi minyak bumi dari sumur tua yang masih terdapat kandungan minyak bumi berdasarkan pertimbangan teknis dan ekonomis

2. Dalam hal kontraktor tidak mengusahakan dan memproduksi minyak bumi dari sumur tua sebagaimana dimaksud pada ayat 1 , KUD atau BUMD dapat mengusahakan dan memproduksi minyak bumi setelah mendapat persetujuan menteri

3. Pengusahaan dan pemroduksian minyak bumi sebagaimana dimaksud pada ayat 2 dilaksanakan KUD atau BUMD berdasarkan perjanjian memproduksi minyak Bumi dengan kontraktor.

Implikasi dari peraturan tersebut yaitu negara memberikan izin kepada masyarakat untuk mengelola sumur minyak tua sebagai sumber ekonomi masyarakat melalui KUD dan PT Pertamina. Hal ini juga sebagai wujud kepedulian negara terhadap pemerataan ekonomi rakyat.

UU No. 25 tahun 1992 menyebutkan bahwa koperasi merupakan badan usaha yang beranggotakan orang per-orang atau badan hukum koperasi dengan melandaskan kegiatannya berdasarkan prinsip-prinsip koperasi, sekaligus sebagai gerakan ekonomi rakyat yang berdasarkan atas asas kekeluargaan. Jadi koperasi setiap anggota mempunyai kedudukan yang sama dan peran yang sama dalam kegiatan koperasi

Sejarah koperasi (Masngudi: 1990) Awalnya diperkenalkan oleh R. Aria Wiriatmadja di Purwokerto, Jawa Tengah pada tahun 1896. Perkumpulan tersebut bertujuan untuk membantu rakyat kecil dari jeratan utang. perkembangan koperasi semakin baik pada era pergerakan nasional yakni pada masa Budi Utomo. Dengan pemikiran untuk dapat menolong diri sendiri melahirkan koperasi yang bertujuan untuk dapat membantu rakyat agar "berdaya" dan dapat berdiri sendiri.

Koperasi didirikan dengan tujuan untuk memperbaiki nasib orang-orang yang lemah ekonominya dengan jalan kerja sama. Kerja sama adalah dasar dari koperasi ekonomi. Kerja sama dipupuk dan ditanamkan dalam organisasi koperasi. Dalam sejarah bangsa Indonesia kerja sama sudah ada sejak zaman dahulu. Kerja sama yang dikenal dengan istilah gotong royong, saling membantu, tolong menolong, merupakan karakter yang melekat dalam diri bangsa Indonesia.

Ekonomi rakyat Indonesia yang didominasi oleh sektor usaha mikro dan kecil tentu membutuhkan suatu wadah untuk dapat berdikari. Koperasi sebagai suatu badan usaha yang sesuai dengan karakter bangsa Indonesia dan juga secara terang disebutkan dalam Undangundang dasar 1945 memiliki wewenang untuk memberdayakan rakyat. Dengan prinsip seperti yang tercantum dalam bab III, bagian kedua, pasal 5 UU No. 25 tahun 1992 antara lain keanggotaan bersifat terbuka dan sukarela, pengelolaan dilakukan secara demokrasi artinya dari, oleh dan untuk anggota, pembagian SHU secara adil dan kemandirian, pantaslah jika harapan besar disematkan kepada koperasi dalam rangka mencapai kesejahteraan.

Dengan prinsip yang kuat tersebut, tidak heran jika koperasi diharapkan menjadi soko guru pembangun perekonomian. Dengan memiliki banyak koperasi yang maju maka perekonomian akan "berdaya". Namun pada praktiknya dimasyarakat hanya ada beberapa koperasi yang dapat dikatakan sukses. Umumnya masyarakat kurang mengetahui bagaimana kegiatan usaha koperasi.

Koperasi sebagai badan usaha yang berciri khas kekeluargaan memiliki tujuan untuk memajukan kesejahteraan anggota pada khususnya dan masyarakat pada umumnya. Dengan karakteristik koperasi tersebut pemerintah mengambil kebijakan dengan mengeluarkan peraturan menteri, dalam rangka mencapai kesejahteraan masyarakat sekitar pertambangan minyak. Kebijakan tersebut terkait dengan pengelolaan sumur tua, di mana koperasi ditunjuk berperan dalam pengelolaannya.

Sumur minyak yang terletak di desa Wonocolo merupakan sumur minyak peninggalan belanda. Setelah ditinggalkan oleh belanda sumur-sumur ini di Nasionalisasi oleh negara sebagaimana di jelaskan pada Undang-undang No. 86 tahun 1958 tentang nasionalisasi 
perusahaan milik Belanda. Nasionalisasi ini bertujuan untuk memberikan manfaat yang lebih besar dan sebagai upaya dalam memakmurkan rakyat.

Dalam upaya untuk memakmurkan rakyat melalui pemanfaatan sumur-sumur bekas peninggalan Belanda, Pemerintah memberikan izin kepada KUD agar sumber daya yang dimiliki oleh negara dapat memberikan manfaat kepada negara dan juga memeratakan pendapatan rakyat dari sumber daya tersebut. Sebagai badan usaha yang berada di lini terbawah sebagai kepanjangan tangan dari pemerintah koperasi diharapkan dapat menjadi media yang mampu untuk mewujudkan cita-cita negara dalam memakmurkan rakyat.

Sebagaimana dijabarkan dalam peraturan menteri ESDM No. 01 tahun 2008 tentang penguasaan pertambangan sumur tua. Dalam peraturan tersebut pemerintah memberikan izin kepada BUMD dan atau Koperasi sehingga SDA dapat memberikan manfaat dan penerimaan yang maksimal bagi Negara untuk sebesar-besar kemakmuran rakyat. Terkait dengan hal ini, koperasi Sumber Pangan merupakan koperasi yang ditetapkan sebagai pengelola penambangan sumur tua. Uniknya koperasi ini tidak bergerak dibidang produksi, ataupun pemasaran. Koperasi sumber pangan berperan dalam penyediaan jasa angkut.

Koperasi memiliki peran penting dalam usaha penambangan sumur minyak tua, sesuai dengan peraturan yang berlaku. Tanpa adanya campur tangan koperasi usaha pengelolaan pertambangan mustahil dapat terlaksana, artinya sumur tua yang ada di daerah Wonocolo tersebut tidak dapat memberikan manfaat kepada masyarakat.

Dalam rangka menyejahterakan anggota koperasi sumber pangan berperan dalam menjalin kerja sama/ bermitra dengan masyarakat penambang dan dengan Pertamina. Selain itu KUD sumber pangan juga membantu penambang yang kekurangan modal dengan memberikan pinjaman. Peran lain koperasi ini adalah dengan memanajemen hasil penjualan minyak mentah. Penambangan tradisional melakukan kerja dengan risiko yang tinggi, sedangkan mereka bekerja tidak dilengkapi dengan alat pengaman diri yang mencukupi, dengan kekurangan ini koperasi dapat memanajemen hasil penjualan minyak mentah, dengan pembagian $70: 30.70$ persen hasil penjualan diterima oleh penambang, sedangkan bagian 30 persen dikelola oleh koperasi yang di anggarkan untuk pajak, asuransi dan operasional koperasi. Bagi masyarakat setempat koperasi memberikan kesempatan kerja, yakni bagi masyarakat yang memiliki mobil tanki untuk mengangkut hasil tambang.

KUD Sumber pangan memiliki kekuatan dalam memonopoli sumur tua di desa Wonocolo. Hal ini merupakan kekuatan dan juga bisa dikatakan kelebihan utama dari KUD Sumber pangan. Kekuatan ini seharusnya dapat dimanfaatkan untuk pengembangan usaha koperasi, mengingat kebutuhan para anggota koperasi yang juga merupakan penambang minyak terkait dengan perlengkapan penambangan ataupun keperluan lain dapat menjadi potensi usaha. Namun sangat disayangkan koperasi ini belum memanfaatkan hal tersebut. Belum ada pengembangan unit usaha lain yang dijalani oleh KUD Sumber Pangan.

\section{SIMPULAN}

Koperasi sebagai suatu badan yang diberikan kepercayaan oleh pemerintah sebagai wadah dalam pengelolaan sumur tua sehingga SDA dapat memberikan manfaat dan penerimaan yang maksimal bagi Negara untuk sebesar-besar kemakmuran rakyat. Pemberdayaan ekonomi yang dilakukan oleh koperasi sumber pangan melalui fasilitas modal dan sebagai wadah bagi masyarakat sekitar lokasi sumur tua untuk dapat memanfaatkan sumur tua sebagai sumber pendapatan.

\section{DAFTAR PUSTAKA}

Iryanti, Rahma. 2014. Kemiskinan dan ketimpangan di Indonesia :Permasalahan dan tantangan. Yogyakarta: Kementrian BPPN/ Bapennas

Kartasapoetra, G. dkk. 2001. Koperasi Indonesia. Jakarta: PT Rineka Cipta 
Hatta, Moh. 2015. Membangun Koperasi dan Koperasi Membangun. Jakarta: Kompas.

Heriyono. 2012. Peran koperasi dalam Pengembangan Perekonomian Rakyat. Jurnal Ekonomi ISSN: 2302-7169 Vol. 1 No. 1 September-Desember 2012

Masngudi. 1990. Penelitian tentang Sejarah Perkembangan di Indonesia. Jakarta: Badan Penelitian Pengembangan Koperasi, Departemen Koperasi

MESDM RI. 2008. Pedoman Pengusahaan Pertambangan Minyak Bumi pada Sumur Tua.

Soetrisno, Noer.2003. Koperasi Indonesia: Potret dan Tantangan. Artikel th. 2003 No II smecda.com

BPS. Gini ratio provinsi 2002-2017. BPS.go.id

Bps. Prosentase penduduk miskin menurut provinsi. www.bps.go.id 